\title{
Uptake of Trehalose by Saccharomyces cerevisiae
}

\author{
By ARNOŠT KOTYK AND DANA MICHALJANIČOVÁ \\ Laboratory for Cell Membrane Transport, Institute of Microbiology, Czechoslovak \\ Academy of Sciences, Budejovická 1083, 14220 Prague, Czechoslovakia
}

(Received 6 June 1978)

\begin{abstract}
Trehalose, a storage sugar of baker's yeast, is known not to be metabolized when added to a cell suspension in water or a growth medium and to support growth only after a lag of about $10 \mathrm{~h}$. However, it was transported into cells by at least two transport systems, the uptake being active, with a pH optimum at 5.5. There was no stoicheiometry with the shift of protons into cells observed at high trehalose concentrations. Trehalose remained intact in cells and was not appreciably lost to a trehalose-free medium. The uptake systems were present directly after growth on glucose, then decayed with a half-life of about 25 min but could be reactivated by aerobic incubation with trehalose, maltose, $\alpha$-methyl-D-glucoside, glucose or ethanol. The uptake systems thus induced were different as revealed by competition experiments. At least one of the systems for trehalose uptake showed cooperative kinetics. Comparative analysis with other disaccharides indicated the existence in Saccharomyces cerevisiae, after induction with trehalose, of at least four systems for the uptake of $\alpha$-methyl-D-glucoside, four systems for maltose, together with the two for trehalose, variously shared by the sugars, the total of $\alpha$-glucoside-transporting systems being five.
\end{abstract}

\section{INTRODUCTION}

$\alpha, \alpha$-Trehalose [O- $\alpha$-glucopyranosyl- $(1 \rightarrow 1)$ - $\alpha$-D-glucopyranose] has been known for many years as a reserve oligosaccharide in fungi (e.g., Sussman, 1961) and yeasts (e.g., Panek, 1963 ) as well as in some animal organs (insect haemolymph; Candy \& Kilby, 1059). The possibility of high concentrations of the sugar being present in yeast cells (e.g., Janda \& Kotyk, 1972) has been tacitly assumed to be due to the impermeability of the plasma membrane to trehalose. Growth of certain yeasts on trehalose (see Lodder, 1970) is possible only after a considerable lag period, and an extracellular splitting of the disaccharide by an (inducible) enzyme was thought to be responsible for turning trehalose into a growth substrate.

However, Okada \& Halvorson (1964) observed that trehalose inhibited the uptake of $\alpha$-thioethyl-D-glucopyranoside in baker's yeast and, likewise, Alonso \& Kotyk (1978) observed that it interfered with the uptake of $\alpha$-methyl-D-glucoside and maltose. This prompted us to carry out a more detailed investigation of the trehalose uptake process in baker's yeast; the results are presented here.

\section{METHODS}

Micro-organisms and their cultivation. The Saccharomyces cerevisiae $\mathbf{K}$ strain (1) from distillery yeast, used in much previous work (Kotyk \& Michaljaničová, 1974), was employed throughout. Comparisons were made with the collection strain $S$. cerevisiae RXII (2), with a petite colony mutant RXIIA (3), with a collection strain of $S$. carlsbergensis ( $=S$. uvarum, included now in $S$. cerevisiae) (4) and with its respiration- 
deficient mutant (one of the strains used in the Pilsen brewery) (5), and with the op mutant $_{1}$. cerevisiae (a kind gift of Dr J. Subík of Bratislava) lacking the ATP-ADP transport system in mitochondria (6).

The strains were maintained on wort agar slopes and propagated by aerobic growth for $19 \mathrm{~h}$ (strains 1,2 , 4 and 5) or $24 \mathrm{~h}$ (strains 3 and 6 ) at $30^{\circ} \mathrm{C}$ in the following medium $\left(\mathrm{g} \mathrm{l}^{-1}\right): \mathrm{KH}_{2} \mathrm{PO}_{4}, 2 ; \mathrm{K}_{2} \mathrm{HPO}_{4}, 1 ;\left(\mathrm{NH}_{4}\right)_{2} \mathrm{SO}_{4}$, 2; trisodium citrate, $0 \cdot 3 ; \mathrm{MgCl}_{2} .6 \mathrm{H}_{2} \mathrm{O}, 0 \cdot 1 ; \mathrm{MnSO}_{4} .7 \mathrm{H}_{2} \mathrm{O}, 0 \cdot 1 ; \mathrm{CaCl}_{2}, 0 \cdot 1 ; \mathrm{ZnSO}_{4} .7 \mathrm{H}_{2} \mathrm{O}, 0 \cdot 1$; yeast extract, 3; glucose, 10.

After harvesting, the cells were twice washed in tap water, resuspended in distilled water and then treated in different ways (aeration, induction etc.). Subsequently, the uptake of sugars (trehalose, maltose, $\alpha$ methyl-D-glucoside, D-glucose) was measured with ${ }^{14} \mathrm{C}$-labelled compounds, aerobically, at $30^{\circ} \mathrm{C}$, in about $1.5 \mathrm{ml}$ suspension ( 25 to $40 \mathrm{mg}$ dry $\mathrm{wt} \mathrm{ml}^{-1}$ ); $0.2 \mathrm{ml}$ samples were taken at 1 min intervals with nonmetabolized sugars, or at $20 \mathrm{~s}$ intervals for the first $2 \mathrm{~min}$ with maltose and glucose, or in an exponential time regime $(1,2,4,8,16,32,64 \mathrm{~min})$. The samples were filtered through a Synpor 5 membrane filter $(0.6 \mu \mathrm{m}$ pores) and washed with $2 \mathrm{ml}$ cold distilled water; the filter with pellet was transferred to a scintillation vial with scintillation mixture [ $4 \mathrm{~g}$ 2,5-diphenyloxazole and $0 \cdot 1 \mathrm{mg}$ 1,4-di-2-(5-phenyloxazolyl)benzene in $620 \mathrm{ml}$ toluene and $380 \mathrm{ml}$ ethanol]. Filters were not dried as a higher reproducibility of results was achieved after a strictly standard treatment with wet filters. All trehalose uptake experiments were done in at least three (but mostly six) replicates. The values are generally expressed in relation to a control and their range is shown.

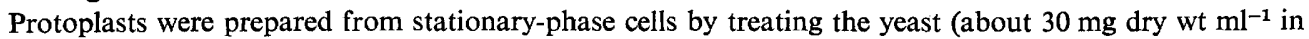
$0.8 \mathrm{M}$-mannitol) for $30 \mathrm{~min}$ at $30^{\circ} \mathrm{C}$ with snail enzyme $\left(30 \mathrm{mg} \mathrm{ml}^{-1}\right)$ and $\beta$-mercaptoethanol $\left(0.05 \mathrm{ml} \mathrm{ml}^{-1}\right)$.

Chromatography of cell extracts. Cell suspensions were boiled for $10 \mathrm{~min}$ and the extract was concentrated in a vacuum evaporator. If required, it was treated with $0 \cdot 15 \mathrm{M}-\mathrm{ZnSO}_{4}$ and with $0 \cdot 15 \mathrm{M}-\mathrm{Ba}(\mathrm{OH})_{2}$ to precipitate macromolecules and phosphorylated compounds. Alternatively, it was combined $(50 \mu \mathrm{l})$ with alkaline phosphatase $\left(10 \mu 1\right.$ of a solution containing $10 \mathrm{mg}$ protein $\mathrm{ml}^{-1}$ ) in $0.1 \mathrm{~m}$-glycine buffer, $\mathrm{pH} 10 \cdot 5$, containing $1 \mathrm{~mm}-\mathrm{MgCl}_{2}$ and $1 \mathrm{mM}^{-} \mathrm{ZnCl}_{2}(150 \mu \mathrm{l})$ and incubated for $30 \mathrm{~min}$ at $37^{\circ} \mathrm{C}$. The mixture was then precipitated with $\mathrm{ZnSO}_{4}$ and $\mathrm{Ba}(\mathrm{OH})_{2}$ as above. Samples of concentrated extracts were separated by chromatography on Whatman no. 1 paper either with 1-butanol/acetic acid/water $(4: 1: 5$, by vol.) for a general separation or with methanol/formic acid/water (16:3:1, by vol.) to achieve better separation of phosphorylated sugars. The chromatography was repeated three times for clearer resolution. Spots were detected with Bonner's reagent for $\alpha$-diols and radioactivity was measured in $2 \times 2 \mathrm{~cm}$ squares of the chromatograms, using liquid scintillation spectrometry.

Other procedures. Incorporation of amino acids into proteins was assessed from the radioactivity present in a hot $10 \%(\mathrm{w} / \mathrm{v})$ trichloroacetic acid precipitate of cells incubated with $\mathrm{L}-\left[{ }^{14} \mathrm{C}\right]$ leucine. Respiration of trehalose was measured (i) by conventional Warburg manometry and (ii) by trapping $\mathrm{CO}_{2}$ produced from $\left[{ }^{14} \mathrm{C}\right]$ trehalose in a filter paper disc wetted with $2 \mathrm{M}-\mathrm{KOH}$. The external $\mathrm{pH}$ of cells was measured with a Radiometer glass electrode attached to a digital pH-meter and recorder (Development Workshop, Czechoslovak Academy of Sciences, Prague). All radioactive samples were counted in an Isocap 2 scintillation spectrometer.

Chemicals. Uniformly ${ }^{14} \mathrm{C}$-labelled trehalose, maltose and $\alpha$-methyl-D-glucoside were from The Radiochemical Centre, Amersham; uniformly ${ }^{14} \mathrm{C}$-labelled D-glucose and L-leucine were from the Institute for Research, Production and Uses of Radioisotopes, Prague, Czechoslovakia. Trehalose, maltose, galactose, a-methyl-D-glucoside, 6-deoxy-D-glucose and L-xylose were products of Koch-Light. Cycloheximide (Actidione) was from Upjohn, U.S.A.; nystatin (Mycostatin) was from Squibb, U.S.A. All other chemicals were from Lachema, Brno, Czechoslovakia.

\section{RESULTS}

\section{Trehalose as respiration and growth substrate}

For at least $4 \mathrm{~h}$ after adding trehalose $(0.1$ to $2 \%, \mathrm{w} / \mathrm{v})$ to a Saccharomyces cerevisiae suspension there was no observable increase in the $Q_{\mathrm{O}_{2}}$ or the $Q_{\mathrm{co}_{2}}$. The amount of radioactivity produced in the gaseous phase from $\left[{ }^{14} \mathrm{C}\right]$ trehalose corresponded to $0 \cdot 2 \%$ of that produced from a comparable sample with glucose in the first $15 \mathrm{~min}$ of incubation, and to less than $4 \%$ after $2 \mathrm{~h}$ of incubation. Hence, for the purpose of the present experiments, trehalose was not oxidized.

Growth on trehalose started after a 10 to $12 \mathrm{~h}$ lag phase and then proceeded similarly to growth on D-glucose. This may be associated with the activation of trehalase at a certain degree of starvation (cf. Panek, 1963; Panek \& Mattoon, 1977). 
Table 1. Uptake of $1 \mathrm{mm-trehalose} \mathrm{after} \mathrm{preincubation} \mathrm{with} \mathrm{different} \mathrm{sugars}$ and derivatives $(1 \%)$

Values are expressed relative to the uptake rate after aerobic preincubation in water alone $(=1 \cdot 0)$, its absolute mean values in the respective strains being $0.41,0.14,0.05$ and $0.05 \mu \mathrm{mol} \mathrm{min}^{-1}$ $(\mathrm{g} \text { dry } \mathrm{wt})^{-1}$. The ranges are shown to indicate the relatively wide scatter of values, mainly due to different control levels in different experiments.

\begin{tabular}{|c|c|c|c|}
\hline $\begin{array}{l}\text { S. cerevisiae } \\
\text { strain }\end{array}$ & $\begin{array}{c}\text { Preincubated for } 2 \mathrm{~h} \\
\text { with: }\end{array}$ & $\begin{array}{c}\text { Relative } \\
\text { uptake rate }\end{array}$ & $\begin{array}{l}\text { No. of } \\
\text { expts }\end{array}$ \\
\hline $\mathbf{K}$ & $\begin{array}{l}\text { Water } \\
\alpha \text {-Methyl-D-glucoside } \\
\text { Maltose } \\
\text { Trehalose } \\
\text { Glucose } \\
\text { Ethanol } \\
\text { Galactose } \\
\text { Water (in argon) } \\
\text { Trehalose (in argon) } \\
\text { Glucose (in argon) }\end{array}$ & $\begin{array}{l}1 \cdot 0 \\
3 \cdot 7-6 \cdot 1 \\
3 \cdot 7-5 \cdot 5 \\
2 \cdot 7-4 \cdot 7 \\
3 \cdot 3-4 \cdot 5 \\
2 \cdot 6-3 \cdot 6 \\
2 \cdot 1-3 \cdot 0 \\
0 \cdot 9-1 \cdot 0 \\
1 \cdot 0-1 \cdot 1 \\
0 \cdot 4-0 \cdot 7\end{array}$ & $\begin{array}{r}10 \\
12 \\
16 \\
16 \\
6 \\
3 \\
3 \\
3 \\
3\end{array}$ \\
\hline RXII & $\begin{array}{l}\text { Water } \\
\text { Trehalose } \\
\text { Glucose }\end{array}$ & $\begin{array}{c}1 \cdot 0 \\
3 \cdot 6-4 \cdot 8 \\
2 \cdot 9-4 \cdot 1\end{array}$ & $\begin{array}{l}4 \\
4\end{array}$ \\
\hline $\begin{array}{l}\text { RXIIA } \\
\text { (respiration- } \\
\text { deficient) }\end{array}$ & $\begin{array}{l}\text { Water } \\
\text { Trehalose } \\
\text { Glucose }\end{array}$ & $\begin{array}{c}1 \cdot 0 \\
1 \cdot 0-1 \cdot 1 \\
1 \cdot 0-1 \cdot 1\end{array}$ & $\begin{array}{l}3 \\
3\end{array}$ \\
\hline RXIIA op 1 & $\begin{array}{l}\text { Water } \\
\text { Trehalose } \\
\text { Glucose }\end{array}$ & $\begin{array}{c}1 \cdot 0 \\
1 \cdot 4-1 \cdot 8 \\
2 \cdot 0-2 \cdot 6\end{array}$ & $\begin{array}{l}3 \\
3\end{array}$ \\
\hline
\end{tabular}

\section{Intracellular trehalose}

Chromatography of cell extracts after incubation of cells with $\left[{ }^{14} \mathrm{C}\right]$ trehalose, as well as treatment of the sugar phosphate fraction with alkaline phosphatase, showed that at least $95 \%$ of the intracellular radioactivity was present as trehalose, the rest being distributed between a free monosaccharide (presumably glucose) and sugar phosphates. There was clearly no trehalose phosphate present.

\section{'Induction' of trehalose uptake}

The standard treatment of cells after growth and harvesting was a 60 min aeration at room temperature. After this, the cells were incubated for $2 \mathrm{~h}$ with different agents, washed and then the uptake of trehalose was measured in a distilled-water suspension. Table 1 shows that three types of substances increased the subsequent uptake: (i) gratuitous inducers - trehalose and $\alpha$-methyl-D-glucoside, the metabolic conversion of the first being negligible, that of the second about 5 to $8 \%$ as compared with glucose; (ii) inducers maltose; (iii) non-inducer metabolic substrates - glucose, galactose and ethanol. (Enzymes of galactose metabolism were themselves induced during the $2 \mathrm{~h}$ preincubation with galactose).

Apparently, aerobic conditions (or, rather, functional mitochondrial respiration) are essential for both the induction and the stimulation by energy substrates. Under anaerobic conditions glucose actually had an inhibitory effect. The only exception was the brewer's yeast respiration-deficient mutant which showed a slight induction by trehalose. Interestingly maltose uptake was similarly raised after preincubation with glucose or ethanol, as well as maltose or trehalose.

Protoplasts prepared from $S$. cerevisiae K could not be induced to transport trehalose but protoplasts prepared from induced cells retained this ability. 


\section{Table 2. Effect of cycloheximide (CYC) during 'induction' on subsequent uptake of $1 \mathrm{~mm}$-trehalose}

Values are expressed relative to the uptake rate after aerobic preincubation in water alone $(=1 \cdot 0)$. Ranges of four experiments are shown.

$\begin{array}{lc}\text { Preincubated for } 2 \mathrm{~h} \text { with: } & \text { Relative uptake rate } \\ \text { Water } & 1 \cdot 0 \\ 0 \cdot 4 \mathrm{~mm} \text {-CYC } & 1 \cdot 1-2 \cdot 1 \\ 50 \mathrm{~mm} \text {-glucose } & 3 \cdot 4-4 \cdot 1 \\ 50 \mathrm{~mm} \text {-glucose }+0 \cdot 4 \mathrm{~mm}-\mathrm{CYC} & 1 \cdot 1-1 \cdot 5 \\ 25 \mathrm{~mm} \text { trehalose } & 2 \cdot 7-3 \cdot 5 \\ 25 \mathrm{~mm} \text { trehalose }+0 \cdot 4 \mathrm{~mm}-\mathrm{CYC} & 2 \cdot 5-2 \cdot 9 \\ 50 \mathrm{~mm} \text { - } \alpha \text {-methyl-D-glucoside } & 3 \cdot 8-5 \cdot 1 \\ 50 \mathrm{~mm}-\alpha \text {-methyl-D-glucoside }+0 \cdot 4 \mathrm{mM}-\mathrm{CYC} & 2 \cdot 9-3 \cdot 4\end{array}$

To test whether protein synthesis was involved in the 'induction' process, $0.4 \mathrm{~mm}$ cycloheximide was added to the preincubation medium (Table 2). Two opposite effects of this protein-synthesis inhibitor may be discerned. The first (without sugar) consists of blocking the synthesis of a protein (probably a proteolytic enzyme) that degrades the transport system (see Görts, 1969). The second (in the presence of glucose) may be connected with the observation on amino acid transport (Horák et al., 1978) and on de-induction of maltose transport (Alonso \& Kotyk, 1978) that the transport proteins are degraded much faster in the presence of a source of energy (in particular, of mitochondrial ATP), this effect apparently overcoming the inhibition of protease synthesis. The effects appear to be more or less balanced in the presence of trehalose or $\alpha$-methyl-D-glucoside as inducers since these cannot act as energy sources that would raise the intracellular level of ATP.

The effect of cycloheximide on the synthesis of the protease and of the transport protein itself is apparently rather specific and is consistent with the observation that suppression of protein synthesis is not complete. The overall incorporation of $\mathrm{L}_{-}\left[{ }^{14} \mathrm{C}\right]$ leucine into proteins (after $60 \mathrm{~min}$ incubation) was as follows (expressed relative to the incorporation after incubation in water alone $=100): 0.4 \mathrm{~mm}$-cycloheximide, 23; $50 \mathrm{~mm}$-glucose, 290; glucose plus cycloheximide, 37.

The activity of the trehalose transporting system(s) after different treatments is shown in Fig. 1. Unexpectedly trehalose was taken up strongly immediately after harvesting stationary-phase cells. Maltose uptake was found to proceed similarly; the maltose uptake was, in fact, followed by oxidation to $\mathrm{CO}_{2}$, which contrasts with the long-held view (Harris \& Thompson, 1961) that maltose activity only appears after induction with the appropriate inducer. When trehalose was added immediately after harvesting and washing the cells, transport activity increased further (the peak after $20 \mathrm{~min}$ was reproducible but difficult to account for). After addition of glucose, rapid degradation of the trehalose system occurred but a (different) trehalose uptake system was activated subsequently. In water the system decayed exponentially, with a half-life of about $25 \mathrm{~min}$; but if either glucose or trehalose was added at $2 \mathrm{~h}$, new transport systems were activated.

The de-induction of trehalose uptake after trehalose induction has some specific features. After transfer of induced cells to water, no de-induction took place, probably because the inducer was always present in the cells. Glucose or cycloheximide alone stopped this further induction while glucose plus cycloheximide caused an extremely rapid loss of transport activity (cf. Table 2).

\section{Uptake parameters of trehalose}

The uptake of trehalose was linear and permitted us to estimate the parameters quite accurately from the first $5 \mathrm{~min}$ segment. The values of $K_{\mathrm{T}}$ (the half-saturation constant) and of $J_{\max }$ (the maximum transport rate) are summarized in Table 3. It should be noted 


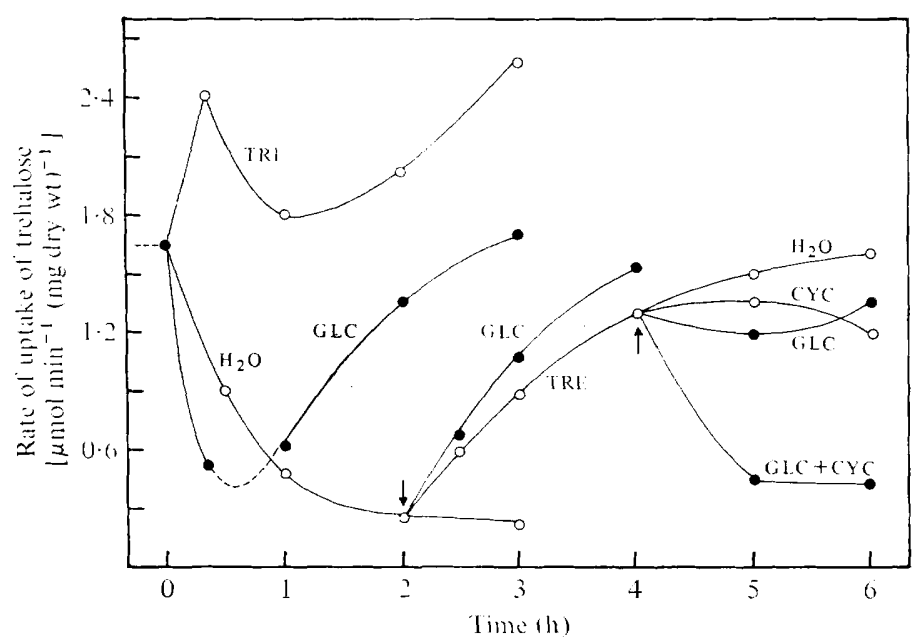

Fig. 1. Effects of different types of incubation on the initial rate of uptake of 1 mM-trehalose, aerobically, at $30^{\circ} \mathrm{C}$. Yeast cells were harvested at the beginning of the stationary phase, washed three times and resuspended in distilled water. Uptake of trehalose was immediately measured in one portion. Other portions were incubated with $25 \mathrm{~mm}$-trehalose (TRE) or 50 mM-glucose (GLC) or water. From the water variant, portions were taken after $2 \mathrm{~h}$ and incubated with glucose or trehalose. After another $2 \mathrm{~h}$, the latter trehalose variant was centrifuged and portions of cells were resuspended in water, $50 \mathrm{~mm}$-glucose, $0.4 \mathrm{~mm}$-cycloheximide (CYC) or a combination of glucose and cycloheximide. At the times shown, uptake of trehalose was assayed.

Table 3. Parameters of the initial rate of trehalose uptake after different treatments

Mean values of four experiments and standard errors are shown.

Treatment

Immediately after growth

After $2 \mathrm{~h}$ in water

After $2 \mathrm{~h}$ in $25 \mathrm{~mm}$-trehalose

After $2 \mathrm{~h}$ in $25 \mathrm{~mm}$-maltose

$$
\begin{gathered}
K_{\mathrm{T}} \\
(\mathrm{mM}) \\
7 \cdot 2 \pm 0 \cdot 8 \\
>500 \\
11 \cdot 8 \pm 2 \cdot 6 \\
15 \cdot 7 \pm 3 \cdot 1
\end{gathered}
$$

$$
\begin{gathered}
J_{\max } \\
{\left[\mu \mathrm{mol} \mathrm{min}^{-1}(\mathrm{~g} \text { dry wt })^{-1}\right]} \\
12 \cdot 3 \pm 2 \cdot 6 \\
\text { Not determinable } \\
16 \cdot 4 \pm 3 \cdot 8 \\
24 \cdot 4 \pm 6 \cdot 7
\end{gathered}
$$

that the half-saturation constants have no significance other than being the concentrations at which the overall rate is one-half of the maximum rate because (i) there are apparently several parallel transport systems present, and (ii) the uptake kinetics of trehalose, both directly after cell growth and after induction with trehalose or maltose, showed a sigmoid pattern (Fig. 2).

In trehalose-induced cells the optimum $\mathrm{pH}$ was 5.5 ; in water-preincubated cells it was 4.5. At the same time, there was no marked effect on the external $\mathrm{pH}$ as trehalose was taken up, either in distilled water or in the presence of $20 \mu \mathrm{M}$-antimycin and $20 \mathrm{~mm}$-2-deoxyD-glucose. Only with a high concentration of trehalose $(10 \mathrm{~mm})$ was there a slight alkalification, its rate being about one-half that observed after addition of maltose under the same conditions. The amount of $\mathrm{H}^{+}$ions thus displaced would correspond to a ratio of $\mathrm{H}^{+}$: trehalose of about $1: 100$.

There was a slight (10 to $12 \%$ ) stimulation of uptake in the presence of $\mathrm{K}^{+}$ions and a very slight one $\left(5\right.$ to $6 \%$ ) in the presence of $\mathrm{Na}^{+}$ions at $50 \mathrm{~mm}$.

There was no kinetic significance in comparing the intracellular radioactivity of trehalose in equilibrium with that in the external medium because (i) the uptake proceeded for at least $3 \mathrm{~h}$ at an appreciable rate provided there was sufficient trehalose in the medium and (ii) trehalose inside the cells was not free to leave into the medium (Fig. 3).

The uptake was affected by various inhibitors as shown in Table 4. 


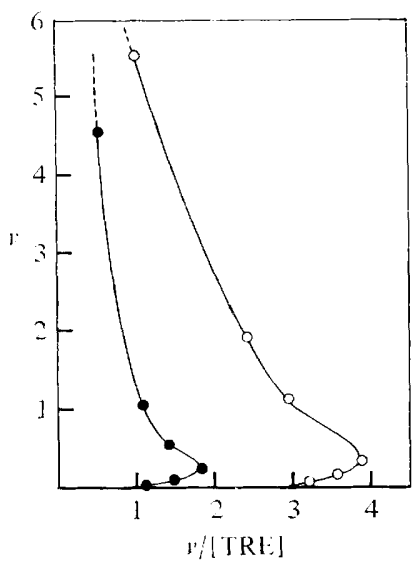

Fig. 2. A Hofstee-Eadie plot of trehalose uptake in Saccharomyces cerevisiae $\mathrm{K}$ immediately after growth $(\bigcirc)$ and after aeration and induction with $25 \mathrm{~mm}$-trehalose $(\bullet) . v$ is expressed in $\mu \mathrm{mol} \min ^{-1}(\mathrm{~g} \text { dry } \mathrm{wt})^{-1}$, [TRE] in mM.

Table 4. Effect of inhibitors on the uptake of $1 \mathrm{~mm}$-trehalose

Yeast cells were aerated for $2 \mathrm{~h}$ either without substrate (A) or with 25 mm-trehalose (B). The mean uptake rates of three experiments are expressed in $\mu$ mol trehalose $\min ^{-1}\left(\mathrm{~g}\right.$ dry wt) ${ }^{-1}$.

\begin{tabular}{lccc} 
& & \multicolumn{2}{c}{ Uptake rate } \\
Inhibitor & Concn (mM) & $\mathrm{A}$ & $\mathrm{B}$ \\
None & - & 0.41 & 1.15 \\
2,4-Dinitrophenol & 0.5 & 0.37 & 0.72 \\
Iodoacetamide & 0.5 & 0.40 & 0.90 \\
Cycloheximide & 0.4 & 0.57 & 1.28 \\
Uranyl nitrate & 0.5 & 0.03 & 0.04 \\
Anaerobiosis & - & 0.40 & 1.09
\end{tabular}

The differences in the apparent $K_{\mathrm{T}}$ and $J_{\max }$ depending on the pretreatment of the cells suggested that trehalose may be transported by several systems. This view was further supported (i) by measuring the extent of mutual competition between trehalose, maltose, $\alpha$-methyl-D-glucoside, and glucose in trehalose-induced cells (the Dixon plots in Fig. 4) and (ii) by defining the specificity of competition with trehalose uptake after different pretreatments (Fig. 5). In addition to various degrees of inhibition, there was a stimulation of uptake in the presence of a potential inhibitor (particularly after $\alpha$-methyl-D-glucoside induction). The same phenomenon was observed in impoverished as well as in trehaloseinduced cells where the metabolically inactive monosaccharides D-xylose, L-xylose and, especially, 6-deoxy-D-glucose brought about as much as a $40 \%$ increase in the initial rate of uptake of trehalose.

\section{DISCUSSION}

Several observations described here deserve comment. The fact that trehalose is taken up by yeast cells in an active process raises the question of how it is retained in the cells without noticeable flow back to the medium. It is not a matter of a highly inward-oriented active transport because metabolic inhibitors affect the uptake only by at most $40 \%$. It is likely that trehalose is sequestered in some cell organelle and that its exchange with the cytosol is very slow (Fig. $3 b$ ).

The uptake is characterized by a positive cooperativity. This cannot be due to the use of several systems by the sugar (although these are also revealed, e.g. in Fig. 2, by the nonlinear negative-slope segment of the curves). The corresponding formula, even if it contains 


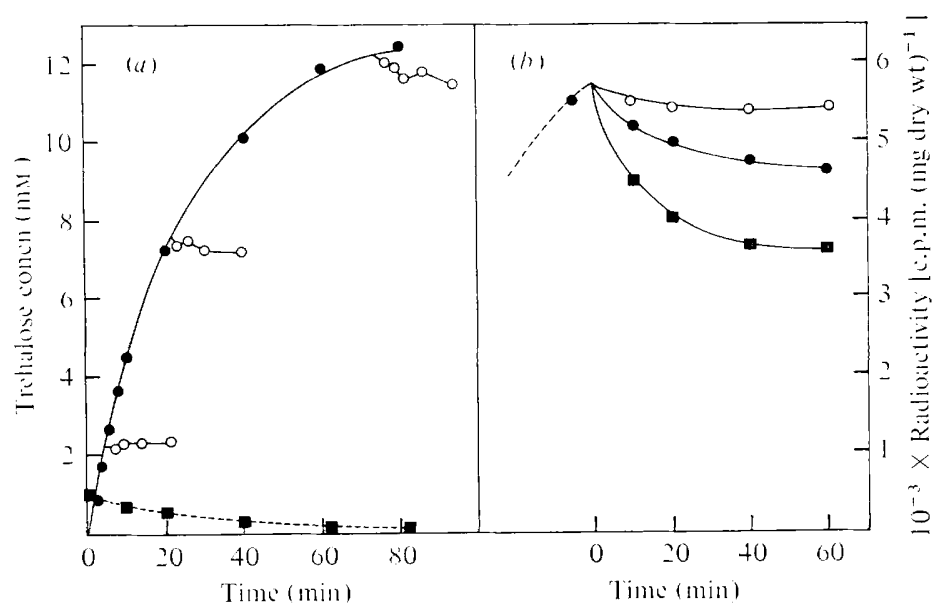

Fig. 3. Influx and efflux of labelled $1 \mathrm{~mm}$-trehalose in baker's yeast. (a) At three points on the uptake curve (O), portions of the suspension were filtered and resuspended in the same volume of water; at intervals, samples from these new suspensions were assayed ( 0 ). 0,0 , Apparent intracellular concentration of trehalose; $\mathbf{\square}$, extracellular concentration of trehalose. $(b)$ Portions of preincubated suspension were filtered and the cells were resuspended in the same volume of water (O), $0.1 \mathrm{~m}$ unlabelled trehalose (O) or $0.01 \%$ nystatin (ם). At intervals, the apparent intracellular concentration of trehalose was determined.

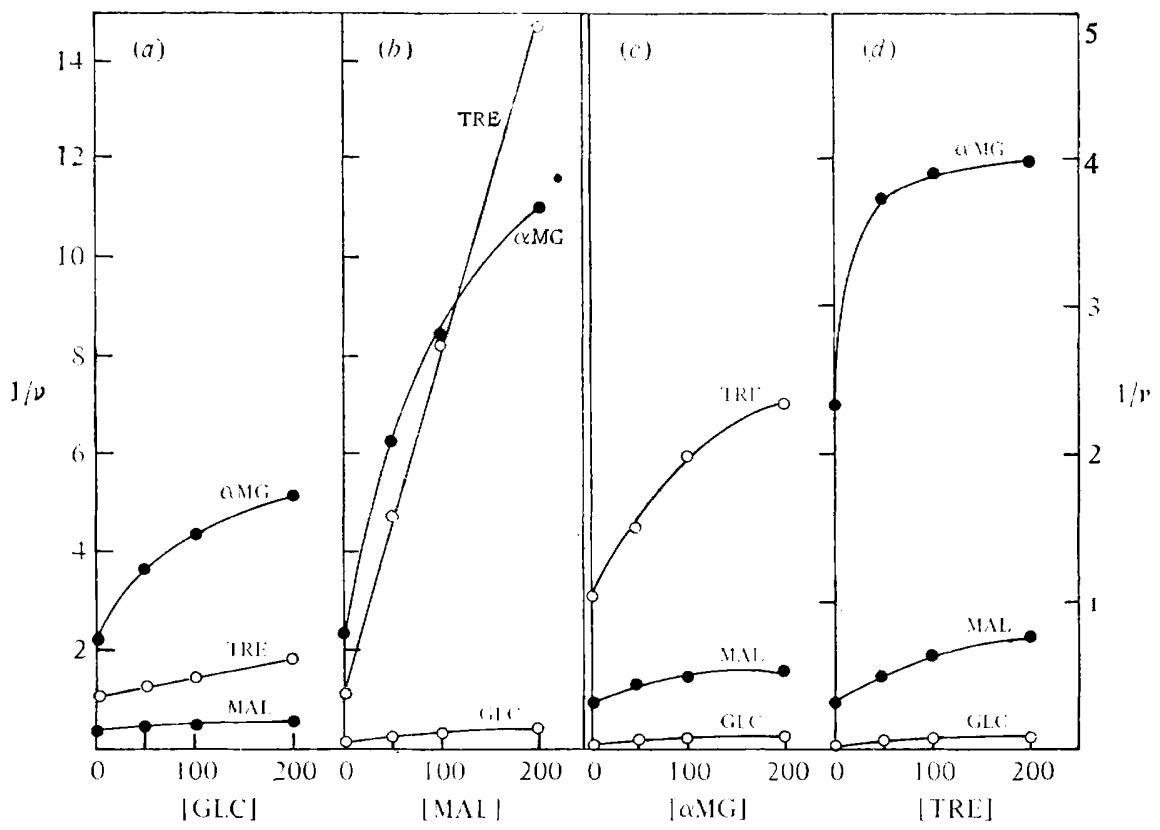

Fig. 4. Dixon plots of uptake of $1 \mathrm{~mm}$ sugars [ $\alpha$-methyl-D-glucoside ( $\alpha \mathrm{MG})$, maltose (MAL), trehalose (TRE), D-glucose (GLC)] in the presence of 50, 100 and $200 \mathrm{~mm}$ competing sugars

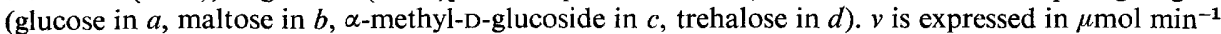
$(\mathrm{g} \text { dry } \mathrm{wt})^{-1}$, concentrations of competing sugars in mm. Only two cases of full inhibition were observed: trehalose uptake as inhibited by glucose and by maltose. Simultaneous competition by trehalose and $\alpha$-methyl-D-glucoside with the uptake of maltose was also of the full inhibition type. 


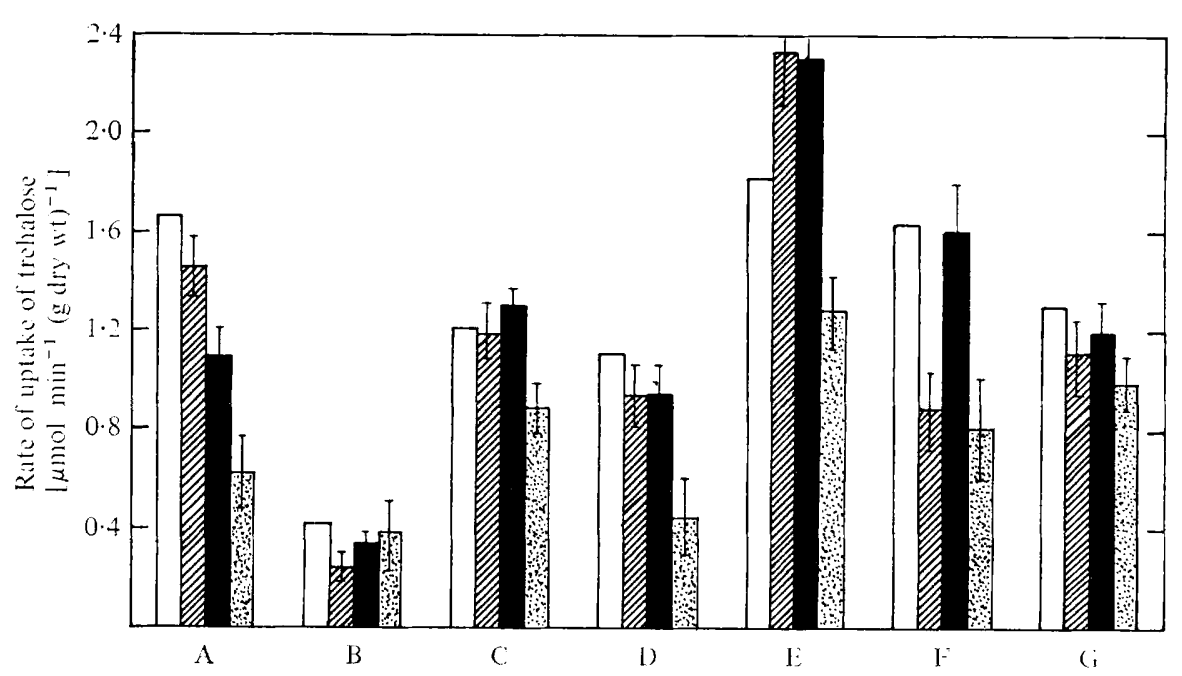

Fig. 5. Effect of various sugars on the initial rate of uptake of $1 \mathrm{~mm}$-trehalose after different pretreatments of cells. In each experiment, uptake was measured in controls (suspensions in water) before and after uptake measurements with competing sugars. Mean values of the controls and relative ranges of three experiments with competing sugars are shown. A, Cells immediately after growth and washing; B, cells after $2 \mathrm{~h}$ aeration in water; cells after $2 \mathrm{~h}$ in the presence of $1 \%(\mathrm{w} / \mathrm{v})$ glucose $(\mathrm{C})$, ethanol (D), $\alpha$-methyl-D-glucoside $(\mathrm{E})$, maltose $(\mathrm{F})$ and trehalose $(\mathrm{G})$. $\square$, Controls; $\bigotimes, 20$ mM-glucose; $\mathbf{\square}, 20 \mathrm{~mm}$ - $\alpha$-methyl-D-glucoside; 国, 20 mM-maltose.

a square or a cube of concentration in the numerator, does not meet the requirements of sigmoidicity (see, e.g., Laidler \& Bunting, 1973). Likewise, it is unlikely that a homotropic nteraction of the allosteric type would be responsible for the effect. It appears that a heterotropic effect (not necessarily on a subunit protein) is involved where both trehalose itself and other sugars (L-xylose, 6-deoxy-D-glucose) may act as positive effectors. A possible explanation of the cooperativity would lie in an activation of the transport system by its substrate which would make the total carrier concentration dependent, either linearly or hyperbolically, on the transported substrate concentration. This would under all conditions give rise to positive cooperativity, the formula for the rate being of the type $J_{\mathrm{s}}=\mathrm{ks} s^{2}$ / $\left(\mathrm{a} s^{2}+\mathrm{b} s+\mathrm{c}\right)$, where $s$ is the concentration of transported substrate and the other symbols are constants.

The source of energy does not appear to lie solely in the $\mathrm{H}^{+}$gradient across the membrane - the $\mathrm{pH}$ dependence curve is symmetrical about an optimum at $\mathrm{pH} 5 \cdot 5$, and 2,4-dinitrophenol only causes a minor reduction of uptake. The alkalification of the external medium observed after addition of high concentrations of trehalose might be due to a competition for energy reserves as discussed by Kotyk (1979). This contrasts with the uptake of maltose described by Seaston et al. (1973) and by Serrano (1977). However, their findings may pertain to a situation where one of the maltose carriers heavily predominates.

The present results point to the complex situation existing in the transport of sugars by baker's yeast.

1. There are at least seven systems involved in the transport of monosaccharides and $\alpha$-glucosides after induction with trehalose, as indicated in Table 5, which is based on data of this paper and on previous reports (Kotyk, 1967; Kotyk et al., 1975). For maltose, this is consistent with the conclusion reached by Zimmermann et al. (1973) about the plurality of non-maltase genes participating in the utilization of maltose. The table shown here is by no means definitive for the following reasons: (i) there may be more systems with a low capacity and/or a similar specificity that could not be detected; (ii) it is possible that some sugars, e.g. glucose, inhibit by an allotopic mechanism but are not themselves 
Table 5. Transport systems invclved in the uptake of sugars in baker's yeast after induction with trehalose

A, A specific $\alpha$-methyl-D-glucoside system; B and E, $\alpha$-methyl-D-glucoside and maltose systems; C, non-specific $\alpha$-glucoside system (possibly the one described by Okada \& Halvorson, 1964); $\mathrm{D}$, disaccharide system excluding $\alpha$-methyl-D-glucoside (the maltose permease of Görts, 1969); F, constitutive glucose system (Kotyk et al., 1975); G, non-specific pyranose system (Kotyk, 1967).

$\begin{aligned} & \text { Transported } \\ & \text { sugar }\end{aligned}$
D-Glucose
Maltose
$\alpha$-Methyl-D-glucoside
Trehalose

\begin{tabular}{lllllll}
\multicolumn{1}{c}{} & \multicolumn{1}{c}{ System } \\
A & B & C & D & E & F & G \\
& & + & + & & + & + \\
& + & + & + & + & & \\
+ & + & + & & + & & \\
& & + & + & & &
\end{tabular}

transported; (iii) considerations based on the maximum rates of uptake by individual systems may be wrong because the maximum rates of uptake of different sugars by a given system may be different and this difference will go undetected unless suitable mutants are prepared; (iv) the scheme was derived for the situation after induction with trehalose after preincubation with other sugars, the competition patterns differ, suggesting a different participation of the postulated (but possibly also additional) transport systems.

2. The four or five carriers functioning in the uptake of $\alpha$-glucosides appear to be degraded rather rapidly (although at different rates), cycloheximide affecting (i) the resynthesis of the transport proteins and (ii) the synthesis of specific proteases degrading the transport proteins. Either of the two effects may predominate. A clear indication of the positive dependence of the protease activity on the presence of glucose (probably through the mediation of mitochondrial ATP) was again obtained (cf. Alonso \& Kotyk, 1978; Horák et al., 1978). This would add another type of regulation of enzyme degradation to the three proposed by Holzer (1977).

3. The various carriers can be 'induced' to function not only by proper inducers (trehalose, $\alpha$-methyl-D-glucoside) but, even more strikingly, by non-inducer sources of metabolic energy (glucose, ethanol). The peculiar character of both these types of induction is underlined by its onset practically immediately after the inducer is added (Fig. 1). This contrasts with the typical induction after addition of galactose in which the first transport activity appears after 30 to $40 \mathrm{~min}$ and then rises rapidly. An unexpected discovery was the highly active transport of both trehalose and maltose immediately after growth on glucose. Hence, some of the transport systems must be constitutively present but are rapidly degraded. The stimulating effect of preincubation of energy-depleted yeast with glucose and other energy sources may have gone unnoticed in earlier work (Görts, 1969; Siro et al., 1977) since glucose has an opposite effect in systems where maltose metabolism has already been induced.

Preliminary experiments using rubomycin (daunomycin) indicate that transcription is involved in the induction process due to glucose even more than with trehalose as inducer. 


\section{REFERENCES}

Alonso, A. \& KotyK, A. (1978). Apparent halflives of sugar-transport proteins in baker's yeast. Folia microbiologica 23, 118-125.

CANDY, D. J. \& Kilby, B. A. (1959). Site and mode of trehalose biosynthesis in the locusts. Nature, London 183, 1594-1595.

Görts, C. P. M. (1969). Effect of glucose on the activity and the kinetics of the maltose uptake system and of $\alpha$-glucosidase in Saccharomyces cerevisiae. Antonie van Leeuwenhoek 35, 233-234.

Harris, G. \& Thompson, C. C. (1961). The uptake of nutrients by yeasts. III. The maltose permease of a brewing yeast. Biochimica et biophysica acta 52, 176-183.

Holzer, H. (1977). Function and regulation of yeast intracellular proteinases. In EUCHEM Conference on Metabolic Reactions in the Yeast Cell, Helsinki, pp. 21-22.

Horák, J., Kotyk, A. \& Ř́lHová, L. (1978). Stimulation of amino acid transport in Saccharomyces cerevisiae by metabolic inhibitors. Folia microbiologica 23, 286-291.

JANDA, S. \& KоTYK, A. (1972). Some features of carbohydrate metabolism in Rhodotorula glutinis. Folia microbiologica 17, 461-470.

KoтYк, A. (1967). Properties of the sugar carrier in baker's yeast. III. Specificity of transport. Folia microbiologica 12, 121-131.

Kотук, A. (1979). Different energy sources for membrane transport in yeasts. Pure and Applied Chemistry (in the Press).

KotyK, A. \& Michaljaničová, D. (1974). Nature of uptake of D-galactose, D-glucose and $\alpha$ methyl-D-glucoside by Saccharomyces cerevisiae. Biochimica et biophysica acta 332, 104-113.

KotyK, A., Michaljaničová, D., Vereš, K. \& Soukupová, V. (1975). Transport of 4-deoxy- and 6-deoxy-D-glucose in baker's yeast. Folia microbiologica 20, 496-503.
LAidler, K. J. \& Bunting, P. S. (1973). The Chemical Kinetics of Enzyme Action, 2nd edn. Oxford: Clarendon Press.

LodDer, J. (1970). The Yeasts. Amsterdam: North Holland.

Okada, H. \& Halvorson, H. O. (1964). Uptake of $\alpha$-thioethyl-D-pyranoside by Saccharomyces cerevisiae. II. General characteristics of an active transport system. Biochimica et biophysica acta 82, 547-555.

PANeK, A. (1963). Function of trehalose in baker's yeast (Saccharomyces cerevisiae). Archives of Biochemistry and Biophysics 100, 422-425.

PaneK, A. \& Mattoon, J. R. (1977). Regulation of energy metabolism in Saccharomyces cerevisiae. Archives of Biochemistry and Biophysics 183, 306-316.

Seaston, A., Inkson, C. \& Eddy, A. A. (1973). The absorption of protons with specific amino acids and carbohydrates by yeast. Biochemical Journal 134, 1031-1043.

Serrano, R. (1977). Energy requirements for maltose transport in yeast. European Journal of Biochemistry 80, 97-102.

Siro, M. R., Hautera, P. \& Lövgren, T. (1977). Influence of glucose on the maltose uptake of Saccharomyces cerevisiae. In EUCHEM Conference on Metabolic Reactions in the Yeast Cell, Helsinki, pp. 61-62.

Sussman, A. S. (1961). The role of trehalose in the activation of dormant ascospores of Neurospora. Quarterly Review of Biology 36, 109-116.

ZimmermanN, F. K., Khan, N. A. \& Eaton, N. R. (1973). Identification of new genes involved in disaccharide fermentation in yeast. Molecular and General Genetics 123, 29-41. 